\title{
EURASIAN MINERAL WATER: MATHEMATICAL MODELING, CLASSIFICATION AND ASSESSMENT OF THEIR IMPACT ON THE BIOCHEMICAL COMPOSITION OF HUMAN BLOOD
}

\author{
Nikolay Kornilov $^{\mathrm{a}^{*}}$, Elena Kornilova ${ }^{\mathrm{b}}$, Elena Stepanenko ${ }^{\mathrm{a}}$ \\ ${ }^{a}$ Stavropol State Agrarian University, 12, Zootechnicheskii per., Stavropol 355000, Russian Federation, \\ ${ }^{b}$ Innovative Company "Stavropol-ARSIO", 384, Lenina str., Stavropol 355006, Russian Federation, \\ "e-mail: nkornilov@26.ru; phone:(+7 903)41688 41; fax: (+7 865) 2263449
}

\begin{abstract}
In the article we give the results of comparative analysis of the composition of the Eurasian hydromineral resources and we implement the assessment of their impact on the physiological condition of an organism of the person according to biochemical studies of venous blood. Processing of initial data on the composition and properties of mineral waters chloride-hydrocarbonate, sulphate-hydrocarbonate and chloridesulphate types and venous blood are made using the method of mathematical modeling, developed by the authors of this article. It is shown that in the balneological impact hydromineral resources on the body hemoglobin and oxygen in the blood increases, glucose decreases, and acid-base $\mathrm{pH}$ shifts to high alkalinity.
\end{abstract}

Keywords: minerals water, blood, modeling, classification.

\section{Introduction}

Natural mineral waters are natural resources widely applied in medicine, food industry and a number of other fields of manufacture. The geographical expansion of extraction, bottling and spa applications of medicinal mineral waters and mud, has led to the necessity of a system for monitoring and estimating parameters for: quality, origin, composition and properties of various mineral water and mud.

The biological efficacy of salted - waters systems upon human body is largely dependent on their composition and properties through a mathematical function, usually approximated by statistical methods of the linear regression equation. Nowadays it is important to assess the quality of mineral waters using experimental data of chemical and physic-chemical analysis (total salinity, ionic composition, acid-base balance, conductivity and some other characteristics). Generic requirements for the ionic composition and salinity for the different types of mineral waters given by national standards and data (on separate regional waters) are published in various scientific journals and on Internet sites.

However, until now, the general model of mineral waters`classification has not been developed which allows estimating quantitatively the conformity of regional mineral waters to the reference waters of certain types, groups and classes.

Quoted in the national standards in Russian Federation, CIS and EU tracts of mineral waters are divided into types, groups and subgroups (classes), mostly from the values of total salinity and ionic composition (of salt systems), in certain ranges of concentration, whose boundaries are chosen at random, and that is major disadvantage of existing systems standardization.

The purpose of this work consisted in the establishment of the quantitative dependences connecting composition and properties of the regional Eurasian mineral waters chloride-hydrocarbonate, sulphatehydrocarbonate and chloride-sulfate type on the basis of a mathematical model developed by us for the classification of mineral waters, using the characteristic parameters calculated from experimental data on the chemical composition of waters [1].

The paper assessed the composition of some mineral waters in Russian Federation, CIS and the EU, the lake brine and squeezed water, medicinal sulphide mud and dark-gray clay sediments underlying dolomite marl, a natural impermeable horizon of salty lakes in Russian Federation and Romania.

\section{The estimated characteristic parameters of the natural waters (Research method)}

In order to estimate the applied parameters for water identification, we have been introduced the notions of the "characteristic indicator" of the water and their relation with the chemical composition and total salinity of waters $[2]$.

The phrase "characteristic indicator" refers to those functions of the system, through which, or through whose derivatives, can be expressed in explicit form the composition and mass properties of water-salt systems. In this paper we are talking about Eurasian natural mineral waters of different genesis and metamorphism.

As the initial parameters accepted for the mathematical description of structure of water-salt systems of mineral waters, the following amounts have been entered:

1. $\bar{M}$ - The total mineralization of water, $\mathrm{g} / \mathrm{dm}^{3}$.

The value $\bar{M}$ can be calculated from a known parity in chemistry: 


$$
\bar{M}=M \cdot C_{n}
$$

where: $M$ - the gram-equivalent of a salt system of mineral water, g/eqv.; $C_{n}-$ concentration of salts in solution, $\mathrm{eqv} / \mathrm{dm}^{3}$.

The value $M$ is calculated from equation (1) and is a function of one variable $X_{i} / X_{j}$.

2. The dependence $M$ of the ratio $X_{i} / X_{j}$ presented in the form of the equation:

$M=a\left(X_{i} / X_{j}\right)^{b}$,

where: $X_{i} / X_{j}$ - the ratio of equivalent fractions anions $X_{\mathrm{Cl}^{-}} / X_{\mathrm{HCO}_{3}^{-}}, X_{\mathrm{SO}_{4}^{2-}} / X_{\mathrm{HCO}_{3}^{-}}$and $X_{\mathrm{Cl}^{-}} / X_{\mathrm{SO}_{4}^{2-}} ; a$ and $b$ - constants.

The value $M$ adopted by us as the first characteristic indicator that has investigated the water of different ionic composition in a certain sequence in magnitude relations $X_{i} / X_{j}$. Characteristic parameter $M$ is a well-defined value of the salt solution and depends on the nature of dissolved salts, the composition and concentration of ions, forming a salt solution.

We have previously shown that the dilution of the solution with a given value of demineralized water does not change its value. Solutions of different concentrations with similar values $x_{i} / X_{j}$ belong to the same subgroup (class) of water. Solutions with close relationships $X_{i} / X_{j}$ constitute a certain class of mineralized water.

3. The evaluation study of water supplies of a class of mineralized waters was carried out with characteristic indicator $\varphi$, calculated from the equation:

$\varphi=A\left(\frac{X_{i}}{X_{j}}\right)^{D}$,

where: $A$ and $D$ are the coefficients $\left(A=a^{2} \cdot b, D=2 b-1\right)$.

Characteristic indicator $\varphi$ can combine mineral water in a separate class of a certain group of mineral waters.

A logarithmic conversation of the equation (3) allows receiving the equation of linear regression for the processing units of the characteristic indicator $\varphi$ methods of mathematical statistics. In this work the base computer program "Statistics-7" was applied.

\section{Results and discussion}

Calculation of characteristic indicator $\varphi$ of different types of mineral water is made by the equations:

a) chloride-hydrocarbonate type $X$

$$
\mathrm{Cl}^{-} / \mathrm{X}_{\mathrm{HCO}_{3}^{-}}
$$

$$
-\log \varphi(\mathrm{Cl} / \mathrm{HCO})=2.5807-1.1524 \log \left(X_{\mathrm{ac}^{-}} / X_{\mathrm{Na}_{3}^{-\frac{3}{3}}}\right)
$$

b) sulphate- hydrocarbonate type $X_{\mathrm{SO}_{4}^{-}} / \mathrm{X}_{\mathrm{HCO}_{3}^{-}}$

$$
-\log \varphi\left(\mathrm{SO}_{4}^{2-} / \mathrm{HCO}_{3}^{-}\right)=3.3946-1.1301 \log \left(\mathrm{X}_{\mathrm{SO}_{4}^{2-}} / \mathrm{X}_{\mathrm{HCO}_{3}^{-}}\right)
$$

c) chloride-sulfate type $X_{\mathrm{Cl}^{-}} / \mathrm{X}_{\mathrm{SO}_{4}^{2-}}[5]$ :

$$
-\log \varphi\left(\mathrm{Cl}^{-} / \mathrm{SO}_{4}^{2-}\right)=3.3096-1.0572 \log \left(\mathrm{Xl}^{-} / \mathrm{X}_{\mathrm{SO}_{4}^{2-}}\right)
$$


The values of the characteristic indicator $\varphi$ of the composition of the some regional Eurasian water depending on the total mineralization and ionic composition.

\begin{tabular}{|c|c|c|c|c|}
\hline No. & $\begin{array}{l}\text { Mineral water, } \\
\text { country }\end{array}$ & $\begin{array}{l}\text { The total } \\
\text { mineralization of } \\
\text { water, } \bar{M}, \mathrm{~g} / \mathrm{dm}^{3}\end{array}$ & $\begin{array}{c}\text { The ratio } \\
X_{i} / X_{j}\end{array}$ & $\begin{array}{c}\text { The value of the } \\
\text { characteristic } \\
\text { indicator, } \varphi\end{array}$ \\
\hline \multicolumn{5}{|c|}{ Chloride-hydrocarbonate type, $\mathrm{X}_{\mathrm{Cl}^{-}} / \mathrm{X}_{U}$} \\
\hline 1. & Imperial, Spain & 3.921 & 0.471 & 907 \\
\hline 2. & Isti-Su Verkhnii, Azerbaijan & 6.082 & 0.614 & 668 \\
\hline 3. & Keiser Friedrich Heilquelle, Germany & 4.549 & 0.635 & 643 \\
\hline 4. & Vesuvio, Italy & 2.128 & 0.666 & 608 \\
\hline 5. & Essentuki No.17, Russian Federation & 12.057 & 0.728 & 549 \\
\hline 6. & Biskirchener Karlsalssprudel, Germany & 2.788 & 0.759 & 523 \\
\hline \multicolumn{5}{|c|}{ Sulphate-hydrocarbonate type, $X_{S O_{4}^{2-}} / X_{t}$} \\
\hline 1. & Sulphate Narzan, Russian Federation & 5.219 & 0.794 & 3219 \\
\hline 2. & Smirnovskaya, Russian Federation & 3.615 & 0.847 & 2993 \\
\hline 3. & Apenta, Italy & 1.847 & 0.932 & 2686 \\
\hline 4. & Azurra, Italy & 0.522 & 0.935 & 2676 \\
\hline 5. & Ueberkinger, Germany & 3.848 & 0.953 & 2619 \\
\hline 6. & Boario, Italy & 0.726 & 0.996 & 2492 \\
\hline \multicolumn{5}{|c|}{ Chloride-sulfate type, $X_{\mathrm{Cl}^{-}} / X_{S}$} \\
\hline 1. & Krakowianka, Poland & 2.714 & 0.460 & 4617 \\
\hline 2. & Feodosiiskaya, Russian Federation & 3.957 & 0.540 & 3900 \\
\hline 3. & Dax, France & 0.987 & 0.575 & 3651 \\
\hline 4. & Slanic-Moldova No. 5, Romania & 0.212 & 0.658 & 3168 \\
\hline 5. & Lysogorskaya, Russian Federation & 18.165 & 0.744 & 2784 \\
\hline 6. & Don, Russian Federation & 2.850 & 0.791 & 2610 \\
\hline
\end{tabular}

Table 1 shows the calculated values of the characteristic indicator $\varphi$.

This article also considers the possibility of applying the method of mathematical modeling and application of the characteristic indicator of the composition of $\varphi$ for the estimation of the physiological state of the organism according to biochemical analysis of venous blood of patients of the sanatorium "Techirghiol" (Romania), described in the work [3].

In Tables 2 and 3 it is shown some biochemical indices of chemical composition and properties of blood before and after the adoption of balneological procedures, mud treatment of patients of the sanatorium "Techirghiol". Biochemical blood analysis is made with the device CCXS-6.

With the use of the experimental data (Tables 2 and 3) we calculated characteristic indicator of venous blood of patients of the sanatorium "Techirghiol" (Romania) before and after the Spa treatments with mud.

Characteristic indicator of the ion composition of blood $\varphi^{*}$ before and after the procedures we calculated by the equation:

1. Original indicator $\varphi^{*}, \mathrm{o}$

$-\log \varphi^{*, 0}\left(\mathrm{Cl}^{-} / \mathrm{HCO}_{3}^{-}\right)=2.5718-1.1506 \log \left(\mathrm{X}_{\mathrm{Cl}^{-}} / \mathrm{X}_{\mathrm{HCO}_{3}^{-}}\right)$

2. The value of characteristic indicator $\varphi^{*}$ after procedures:

$-\log \varphi^{*}\left(\mathrm{Cl}^{-} / \mathrm{HCO}_{3}^{-}\right)=2.5033-1.1349 \log \left(\mathrm{X}_{\mathrm{Cl}^{-}} / \mathrm{X}_{\mathrm{HCO}_{3}^{-}}\right)$

In the result of the comparative analysis of composition and properties of Eurasian natural mineral waters using the method of mathematical modeling and introduction of the characteristic indicator of $\varphi$ we established the quantitative relations linking the evaluation of the integral indicator $\varphi$ with mineralization and ionic composition of the water of various types and geographical location of the source of mineral water. 
Biochemical parameters of the chemical composition and properties of human blood before the procedures.

\begin{tabular}{|c|c|c|c|c|c|c|c|}
\hline \multirow{2}{*}{$\begin{array}{l}\text { No. of } \\
\text { the } \\
\text { patient }\end{array}$} & \multicolumn{2}{|c|}{ Ion concentration, $\mathrm{mol} / \mathrm{dm}^{3}$} & \multirow{2}{*}{$\begin{array}{l}\mathrm{pCO}_{2}, \\
\mathrm{mmHg}\end{array}$} & \multirow{2}{*}{$\begin{array}{c}\mathrm{pO}_{2}, \\
\mathrm{mmHg}\end{array}$} & \multirow{2}{*}{$\begin{array}{l}\text { Glucose, } \\
\mathrm{mg} / \mathrm{dL}\end{array}$} & \multirow{2}{*}{$\begin{array}{c}\text { Hemoglobin, } \\
\text { g/dL }\end{array}$} & \multirow{2}{*}{$\mathrm{pH}$} \\
\hline & $\mathrm{HCO}_{3}^{-}$ & $\mathrm{Cl}^{-}$ & & & & & \\
\hline 1. & 29.7526 & 100.755 & 48.2975 & 28.4012 & 180 & 14.7940 & 7.3936 \\
\hline 2. & 25.6601 & 105.293 & 44.2954 & 42.7791 & 80 & 13.6072 & 7.3669 \\
\hline 3. & 28.7327 & 105.032 & 48.4927 & 40.0465 & 87 & 15.0668 & 7.3767 \\
\hline 4. & 29.616 & 104.683 & 48.4537 & 33.3757 & 103 & 14.3005 & 7.4210 \\
\hline 5. & 26.0374 & 103.585 & 40.7284 & 43.7158 & 93 & 13.433 & 7.4097 \\
\hline 6. & 27.4314 & 105.802 & 48.9607 & 45.7622 & 98 & 14.0599 & 7.3524 \\
\hline 7. & 29.4035 & 107.669 & 47.4241 & 42.9389 & 106 & 14.2744 & 7.3964 \\
\hline 8. & 28.8403 & 108.196 & 50.3500 & 25.8367 & 123 & 14.4548 & 7.3620 \\
\hline 9. & 28.9969 & 107.348 & 48.6241 & 29.2395 & 122 & 14.6029 & 7.3795 \\
\hline 10. & 26.9461 & 108.952 & 40.9163 & 51.0594 & 144 & 14.4133 & 7.4226 \\
\hline 11. & 30.0801 & 107.939 & 49.0207 & 29.7467 & 91 & 15.2759 & 7.3919 \\
\hline 12. & 26.5423 & 107.551 & 40.9486 & 63.0600 & 132 & 18.3332 & 7.4157 \\
\hline 13. & 29.2089 & 104.550 & 43.8950 & 32.9255 & 257 & 13.7067 & 7.4271 \\
\hline
\end{tabular}

Table 3

Biochemical parameters of the chemical composition and properties of human blood after the procedures.

\begin{tabular}{|c|c|c|c|c|c|c|c|}
\hline \multirow{2}{*}{$\begin{array}{l}\text { No. of } \\
\text { the } \\
\text { patient }\end{array}$} & \multicolumn{2}{|c|}{ Ion concentration, $\mathrm{mol} / \mathrm{dm}^{3}$} & \multirow{2}{*}{$\begin{array}{l}\mathrm{pCO}_{2}, \\
\mathrm{mmHg}\end{array}$} & \multirow{2}{*}{$\begin{array}{c}\mathrm{pO}_{2}, \\
\mathrm{mmHg}\end{array}$} & \multirow{2}{*}{$\begin{array}{l}\text { Glucose, } \\
\text { mg/dL }\end{array}$} & \multirow{2}{*}{$\begin{array}{l}\text { Hemoglobin, } \\
\text { g/dL }\end{array}$} & \multirow{2}{*}{$\mathrm{pH}$} \\
\hline & $\mathrm{HCO}_{3}^{-}$ & $\mathrm{Cl}^{-}$ & & & & & \\
\hline 1. & 32.4535 & 101.8046 & 48.7149 & 39.0512 & 117 & 14.7940 & 7.4618 \\
\hline 2. & 28.1153 & 105.3554 & 45.9244 & 30.0058 & 75 & 14.3457 & 7.3909 \\
\hline 3 . & 25.9409 & 108.4871 & 41.3033 & 54.2744 & 84 & 12.7026 & 7.4020 \\
\hline 4. & 30.4505 & 105.2026 & 49.6929 & 38.1093 & 99 & 13.8033 & 7.4342 \\
\hline 5. & 26.8541 & 103.667 & 41.7745 & 57.4177 & 77 & 13.2129 & 7.4121 \\
\hline 6. & 29.0077 & 105.7348 & 49.5124 & 55.7568 & 83 & 14.0599 & 7.3718 \\
\hline 7. & 26.7567 & 108.6529 & 39.9790 & 87.7730 & 108 & 14.8729 & 7.4296 \\
\hline 8. & 25.1097 & 109.8214 & 37.6393 & 45.4035 & 81 & 15.2222 & 7.4282 \\
\hline 9. & 29.1084 & 105.4624 & 43.0842 & 27.8902 & 115 & 13.4303 & 7.4337 \\
\hline 10. & 26.6644 & 107.7174 & 36.8411 & 48.0840 & 108 & 14.5825 & 7.4636 \\
\hline 11. & 29.5132 & 107.4811 & 48.8783 & 36.4002 & 107 & 14.5903 & 7.3849 \\
\hline 12. & 26.7005 & 107.6161 & 38.7008 & 64.4981 & 108 & 18.4041 & 7.4428 \\
\hline 13. & 28.3394 & 105.4173 & 43.6908 & 41.7544 & 210 & 13.7601 & 7.4160 \\
\hline
\end{tabular}

Studies have shown that the characteristic composition indicator of water-salt solutions $\varphi$ determines the identity of the investigated water to a certain class waters of a group and can be used as the basis of identification of regional water and organization of the system of national monitoring.

Application of methods of mathematical modeling and using of characteristic indicator of $\varphi$ for research of human body fluids, in particular venous blood has shown an opportunity of application of a method for computer diagnostics of the physiological condition of the human body based on the data of biochemical studies of blood [6].

\section{Conclusions}

The evaluation of the composition of the Eurasian mineral waters and human venous blood by using the characteristic indicator $\varphi$ we can make the following conclusions:

1) we suggested mathematical model of water-salt systems regional water and the comparative assessment of their conformity with the reference groups waters chloride-hydrocarbonate, chloride-sulfate and sulfatehydrocarbonate type;

2) we determined the correspondence of the ion composition of water-salt systems mineral waters chloridehydrocarbonate type and human venous blood:

$-\log \varphi($ water $)=2.5807-1.1524 \log \left(X_{\mathrm{Cl}^{-}} / \mathrm{X}_{\mathrm{HCO}_{3}^{-}}\right)$ 
and

$-\log \varphi($ blood $)=2.5718-1.1506 \log \left(X_{\mathrm{Cl}^{-}} / \mathrm{X}_{\mathrm{HCO}_{3}^{-}}\right)$;

3) it is shown that the impact of hydromineral resources and medicinal mud on the human body changes the indicators ionic composition and properties of venous blood: the ratio of chloride and hydrocarbonate ions, acidbase balance, blood oxygenation, the content of hemoglobin, glucose;

4) the characteristic indicator $\varphi$ allows with a high degree of reliability to conduct computer diagnostics of the physiological state of the human body according to biochemical studies of blood.

\section{Acknowledgements}

The authors express their gratitude to $\mathrm{PhD}$ of medicine, associate professor of the Ovidius University (Romania) O. Surdu for the opportunity to participate in joint research on impact of hydroresources of Lake Techirghiol on the physiological state of the human body.

\section{References}

1. Vasiltseva, O.N.; Kornilov, N.I.; Kornilova, E.N. Classification of natural chloride-hydrocarbonate mineral waters (mathematical model and principles of formation composition and characteristics); Agrus: Stavropol, 2009, 180 p. (in Russian).

2. Ermolenko, O.N.; Kornilov, N.I.; Kornilova, E.N. Identification of Eurasian mineral sodium chloridebicarbonate waters. Natural and engineering sciences, 2008, 2, pp. 232-234 (in Russian).

3. Surdu, O. Evaluation of chemical factor of action in sapropelic mud from Techirghiol; Gramar: Bucharest, 2006, 47 p.

4. Kornilov, N.I.; Kudinov, R.A.; Ermolenko, O.N.; Kornilova, E.N. Comparative evaluation of natural sulphatebicarbonate waters of Russia, CIS countries, Germany and Italy. Symposia volumes: Topical issues Ecology and Nature Management; Agrus: Stavropol, 2005, vol. 1, pp. 394-401 (in Russian).

5. Kornilov, N.I.; Surdu, O.; Kornilova, E.N.; Surdu, T.V. Monitoring of the Eurasian natural chlorides-sulfate water using a mathematical model classification of mineral water. Topical issues Ecology and Nature Management; 3-rd International scientific Conference, Paragraph: Stavropol, 2011, pp. 15-22.

6. Kornilov, N.I.; Kornilova, E.N.; Kudinov, R.A. Classification of water-salt systems physiological fluids of humans and animals. Problems Ecology and Protection Agricultural Plants; Symposia volumes, Agrus: Stavropol, 2006, pp. 25-39. 